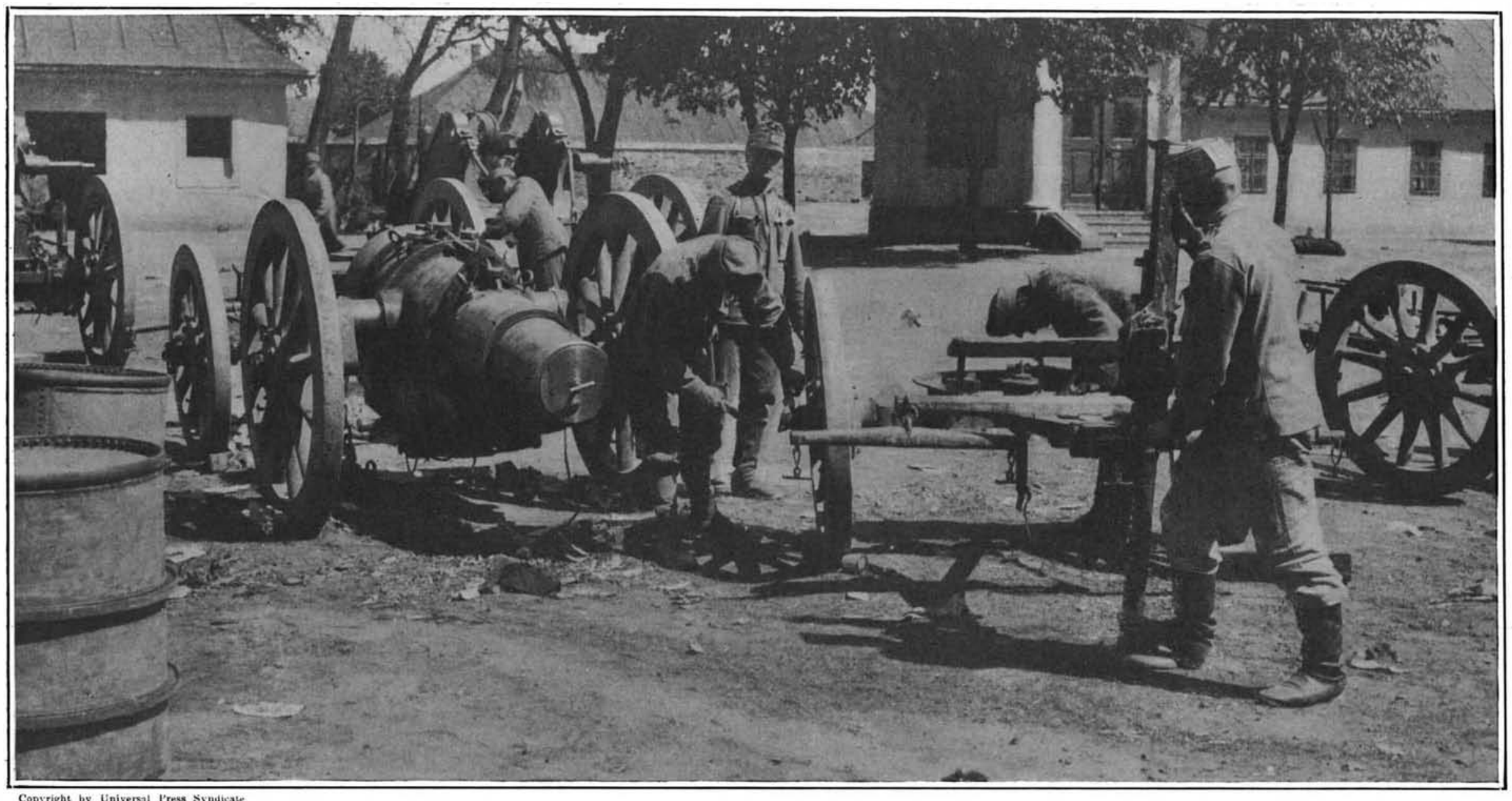

An Austrian 24-centimeter (9.6 inches) howitzer.

\title{
The First Year of the Great War
}

\section{A Review of the Operations in All Theaters of War}

By Capt. Matthew E. Hanna, Recently of the General Staff; U. S. A.

N June 28th, 1914, the world heard of the assassina$O_{\text {tion by a Serb in Sarajevo of the Archduke Francis }}^{N}$ Ferdinand, heir to the Austrian throne. Who could have foreseen at that time the terrible deluge of blood and iron that was to sweep orer Europe as a consequence of this act. Nearly a month passed before Austria sent an ultimatum to Servia on July 23rd, giving her but a few hours in which to frame her reply. The Serrian answer failed to satisfy Austria, and one month to a day after the assassination she declared war on Servia. During this brief period the situation grew in gravity until it became a crisis of greater magnitude than any which had confronted Europe since the days of Napoleon. Soon all Europe was to act as though possessed of an evil spirit of madness and destruction.

What will Russia and Germany do? was the question heard on all sides. Russia, the self-appointed guardian of Serrian sovereignty, was bound to protest

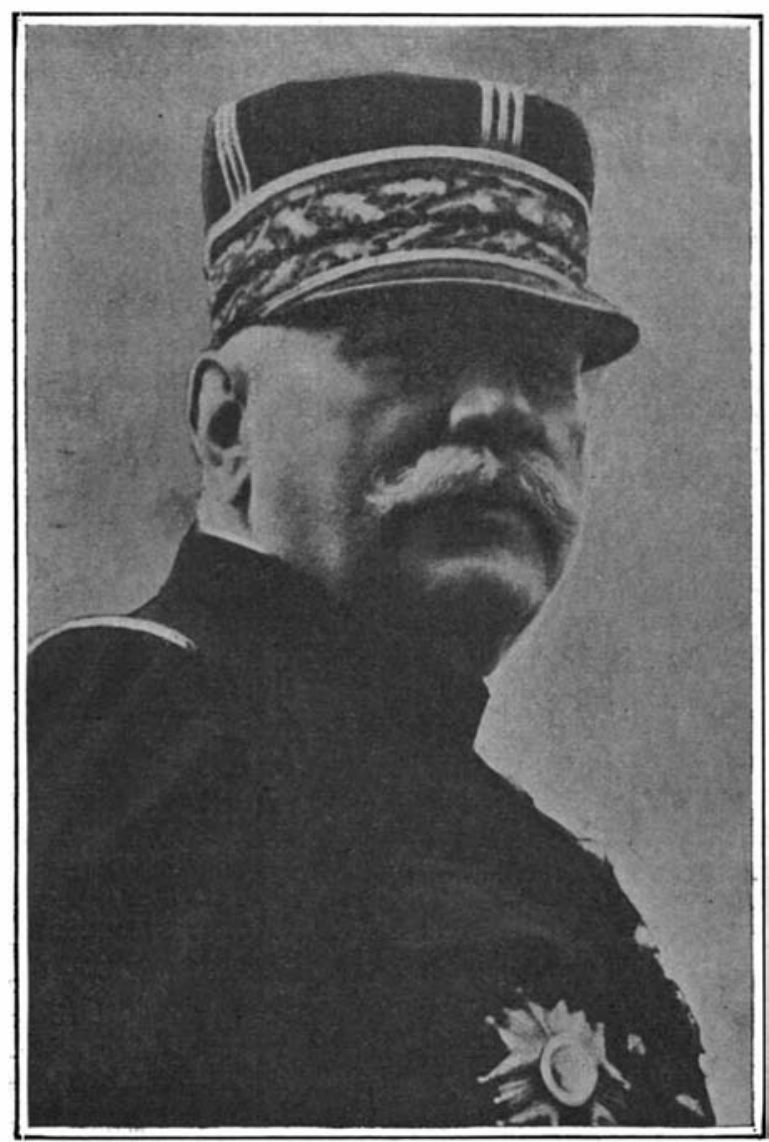

General Joffre, commander-in-chief of the French armies. against Austria's action, and Germany was equally bound to support her Austrian ally should Russia be drawn into the fray. With Germany and A ustria pitted against Russia (and little Servia) there would be slight hope of preventing the conflagration from spreading to France and Great Britain which with Russia formed the Triple Entente. Germany and Austria would the be in a fair position to induce Italy, their ally in the Triple Alliance, to join in their struggle. As the war progressed, minor European states might find it difficult or impossible to remain neutral. Far away Japan was allied to England in a way that would permit her to enter the conflict should her interests seem to demand this. Europen colonies in Africa would certainly become involved. From Australia and Canada armie would be drav'n to serve under the British flag. The world stood on the threshold of the greatest war of all times.

\section{Russia the First to Mobilize.}

Russia promptly answered Austria's ultimatum to Servia by ordering the mobilization of her army. This was Germany's cue to come from behind the scenes, for Russia must not be permitted to secure the great advantage that would result from mobilizing her army before a declaration of war. Germany estimated that her ability to effect a speedy mobilization would more than offset the greater numbers of Russia, and all her plans for beginning a campaign against the RussianFrench-British coalition were based on this assumption. It was not strange, then, that the Russian mobilization order brought an immediate protest from Germany in the form of a demand that mobilization cease. As was to be expected, Russia rejected this demand, and Germany replied by a declaration of war on August 1. But four days had elapsed since Austria had declared war on Servia, yet in that brief time three great nations, Russia, Germany, and France, had been seized by the frenzy of madness and drawn into the vortex of war. Great Britain was last to join in the struggle, but the violation of Belgium's neutrality by Germany a few days later furnished her with an acceptable reason for casting her lot with the Allies. Once more was the map of Europe rolled up to collect dust until some future date when with the dawn of peace and reason it could be opened up and revised.

In all the contending powers the mobilization machinery was at once put in operation, and as was to be expected, the German machine ran smoothest of all, and the Russian machine was slowest; also, as was well known, Germany proposed to make the most of this by a drive into France that would revive memories of Metz and Sedan before Russia could dangerously menace her eastern frontier. She had twenty-five army corns, and it was believed that she would mobilize at least twentythree of these on the French frontier and send but two to her Russian border. To meet this German invasion the French had twenty-one corns, but one was in Africa and two must be kept on the Italian frontier until Italy had declared her intentions. This left France but eighteen corps with which to face the first grand drive of the German twenty-three corns. To offset her weakness, she had the line of wonderful fortresses stretching across her eastern frontier from Luxemburg to Switzerland, effectually barring the only front entrance from Germany to France, she had the prospect of support from England's available army of one hundred and fifty thousand men, and as later events were to prove, she had the powerful assistance of the heroic little Belgian army.

How Germany and Austria Co-operated.

In the eastern theater the Austrian army of sixteen

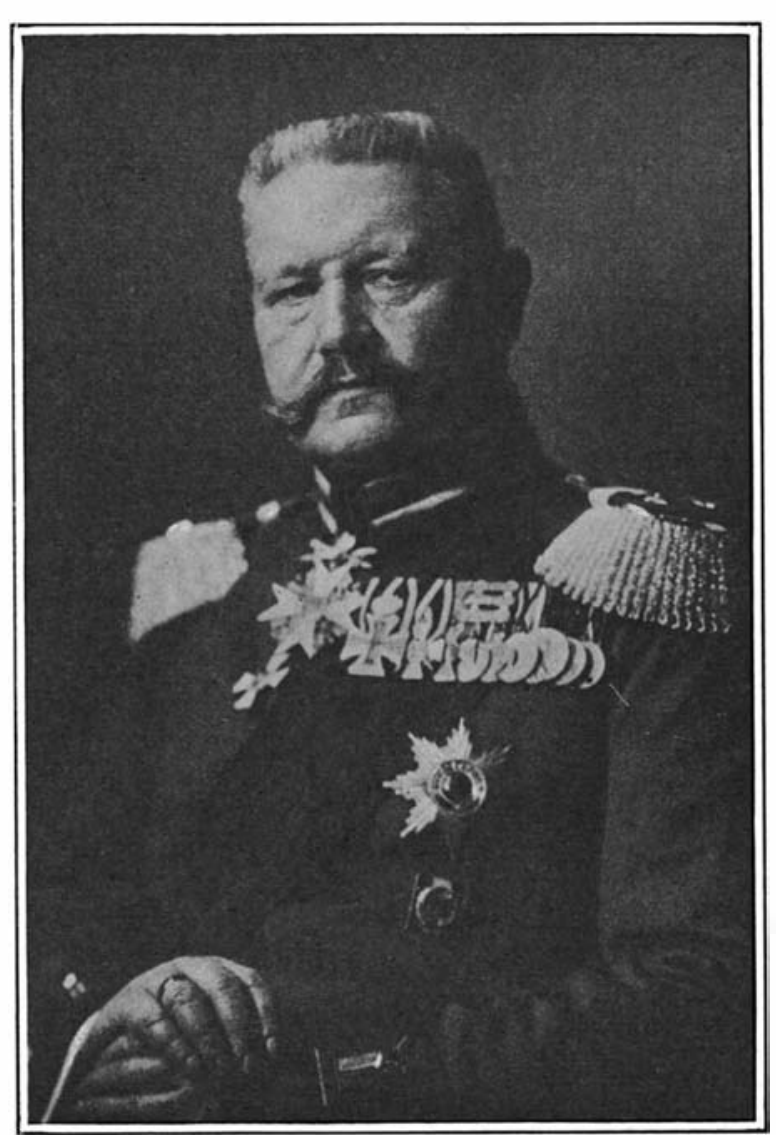

Field-Marshal von Hindenburg, the most conspicuous general on the German side. 
corps had to be divided between the Servian and Russian fronts, with probably ten to twelve corps against Russia and the remainder against Servia. On both fronts she was weaker than her opponent. The Servian army, with an unblemished record in the Balkan wars to give it prestige, numbered about 300,000 men, and against it Austria had not more than 250,000. The Russian hosts opposed to her consisted of twenty corps, or more than a million men, located in European Rus-

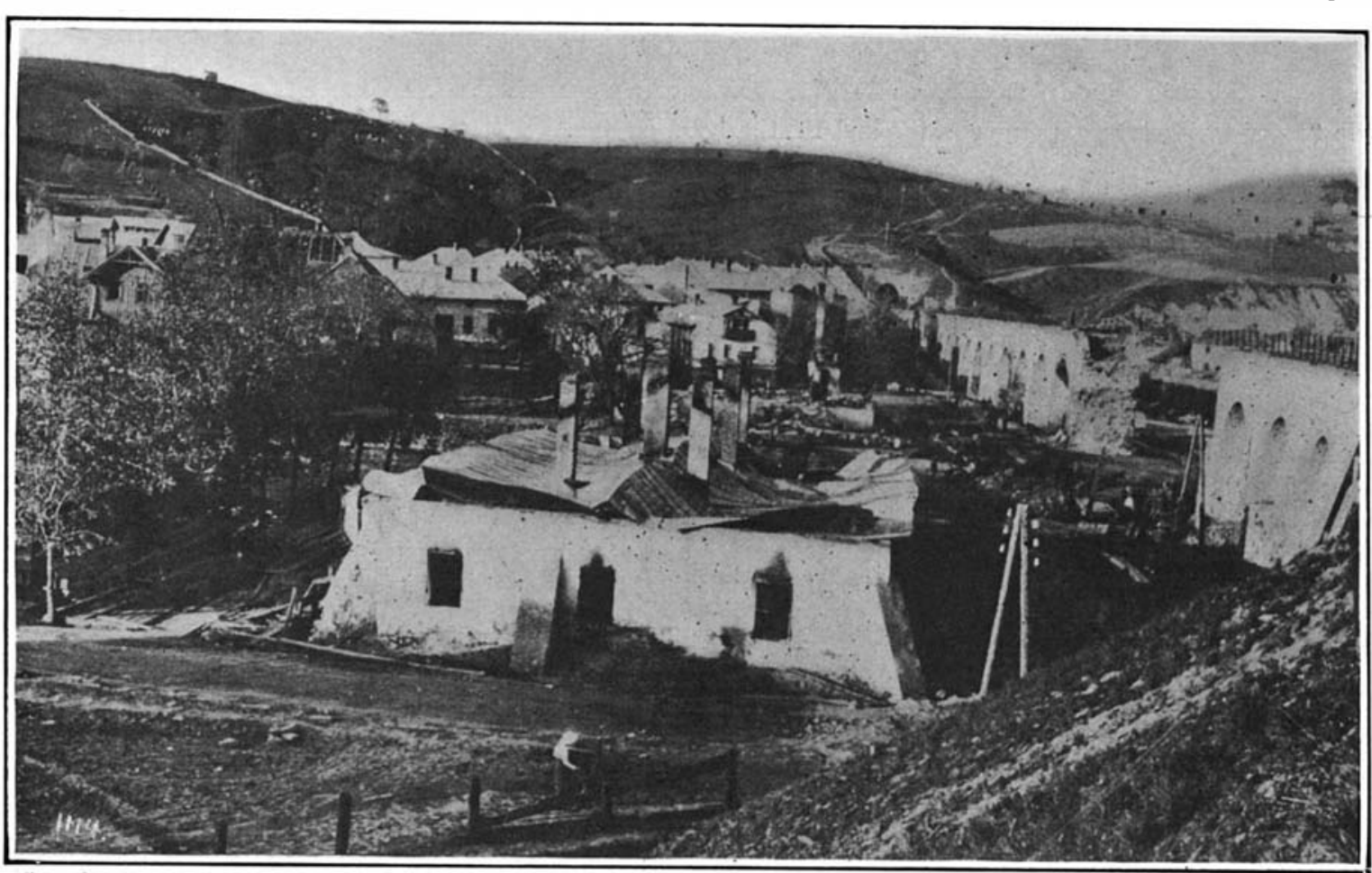

East Galicia has been devastated by the Russians as they retreated. This shows all that is left of a Galician village.

sia, and to meet this rast horde Austria had less than five hundred thousand men. With this comparatively weak army her task was to wage a successful offensive campaign against Servia, while conducting an active defensive campaign against Russia that would hold the Russian army in check until Germany had disposed of France. Austria undertook her purt of the combined Teuton task with enthusiasm and determination no less than that of Germany, but the events of the first few months of the war were to show that she was out matched in both numbers and skill. From the day Austria declared war on Servia to the present time there has been the closest co-operation between the two great Teuton nations. Their initial plan of campaign had been arranged in advance by the two great general staffs. It resulted naturally from the location and strength of the powers forming the Triple Entente. Russia on the east was completely debarred by Germany and Austria from all land communication with her allies, France and (ireat Britain, on the west. So outnumbered were the Teutons b.v the coalition against them, that their only reasonable chance for decisive success"lay in their concentrating in overwhelming force against the enemy on one front at a time, while holding the enemy on the other front as best they could. For one year they have played this simple game of strategy, if not always with complete success, certainly with a larger element of success than the observance of any other central idea could have given them. Their position side by side square between their foes, comhined with the admirable system of strategic railways in the two countries, has made it possible for them to shift their armies with astonishing celerity from one frontier to the other, and has enabled them consistently to adhere to the central controlling idea of their strategy.

Violation of Belgian Neutrality_A Military Necessity.

Coincident with her declaration of war on Russia, Germany began her mobilization on August 1st. The principal mobilization was effected along the Rhine, the line from which all German western operations had their origin. Although the mobilization probably was: not completed until about August 10th, the more advanced frontier troops crossed the western boundary before that date. From the Rhine the vast army advanced along three routes, one to the north through Belgium, one in the center through Luxemburg, and one to the south through Alsace and Lorraine. If the neutrality of Luxemburg and Belgium was not to be violated, the entire army of a million men must enter France by the narrow gateway between Luxemburg and Switzerland, and this had been closed in the years since the calamity of 1870 by a line of fortresses as nearly impregnable as land defenses can be made. So formidable was this barrier that Germany chose to violate the neutrality of Belgium, thereby deliberately inviting the wrath of the world and furnishing England with the pretext she was seeking to justify her entering the struggle.
By August 4th her advance troops had crossed the

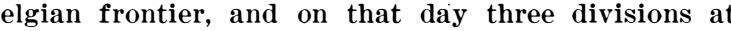
tacked Liége. Belgium had refused Germany's request for permission to cross her territory, and had declare her intention to oppose the German advance. At Liége she began the series of hopeless struggles against tre mendous odds, a sublime effort to maintain her national honor, which have won for her an eternal place in the onor, which have won for her an eternal place in the
nnals of warfare. Instead of marching unoppose

through Belgium, the German army met such stubbor opposition from the Belgians that French soil was not reached until the beginning of the fourth week i August. It had taken this army three weeks to cover the hundred miles of its route across Belgium, and later events revealed the tremendous influence this delay had on the final outcome of the first German drive at Paris.

After three days' bombardment by the huge German howitzers, Liége was entered on August 7 th, and the German army pushed on toward Brussels. At Louvai it again met the Belgians in force, defeated them here on August 19th and entered Brussels the next day. The defeated Belgians fell back to the north on Antwerp, and the Germans pushed on into France. Farthe south Namur fell on August 22nd, opening the way to Charleroi, where the French were defeated August 23rd, the opening weeks of the war and carry the fighting into French territory. On the contrary, they planned to take the offensive in great strength at the earliest possible date after the declaration of war, push across the frontier into Germany and compel the Germans to play to their lead. Shortly before the middle of August they were ready for this move, and began their advance along three lines. The northernmost army moved toward the Belgian frontier, the central army advanced to the east from Verdun, and, the southernmost army pushed into Alsace and Lorraine. Thus it happened that while the great driving force of the German army was fighting its way through Belgium, the bulk of the French army was moving by it to the south in an endeavor to force its way into the lost provinces of Alsace and Lorraine, and so interfere with the systematic development of the German plans that the German forces in Belgium would be weakened by drafts to support their weaker armies in the south. Similarly the German advance through Belgium was calculated to relieve French pressure in Alsace and Lorraine.

For some days this struggle went on to determine whether the initiative should remain with the Germans in the north or the French to the south, but while Germany was sweeping everything before her in Belgium, France was suffering one reverse after another along her entire front, except in Alsace and Lorraine, where her offensive was partially successful. The French central army was turned back in the Ardennes, was defeated roundly at Neufchateau and finally terminated its part of the disastrous attempt at a counter offensive by retreating to the line of French fortifications in the region of Verdun. The southern army found Alsace and Lorraine weakly defended and succeeded in occupying Saarburg and Muelhausen. But by this time the German southern army had come up in sufficient force to check the invasion, and a few days later this French force was driven back to its fortified barrier near Nancy. In the meantime the northern army with Belgian and British aid had been struggling desperately, but vainly, to check the advance of the overwhelming German force in Belgium.

The Germans had won in this opening struggle for the initiative, and for the next few weeks France was compelled to bow to the German will. She immediately began to shift her forces from her right wing on the south to her left wing in front of the Germans coming through Belgium, leaving the defense of her eastern frontier to reduced garrisons in the barrier fortresses. The strategic position of Germany at this time was excellent. Along her entire front her troops had been victorious, Belgian resistance had been overcome, she was within one hundred and fifty miles of Paris, with the weakest fraction of the French army in her front. The world in the future might make her pay dearly for her disregard of what she chose to call a "scrap of paper," but for the present she could be depended on

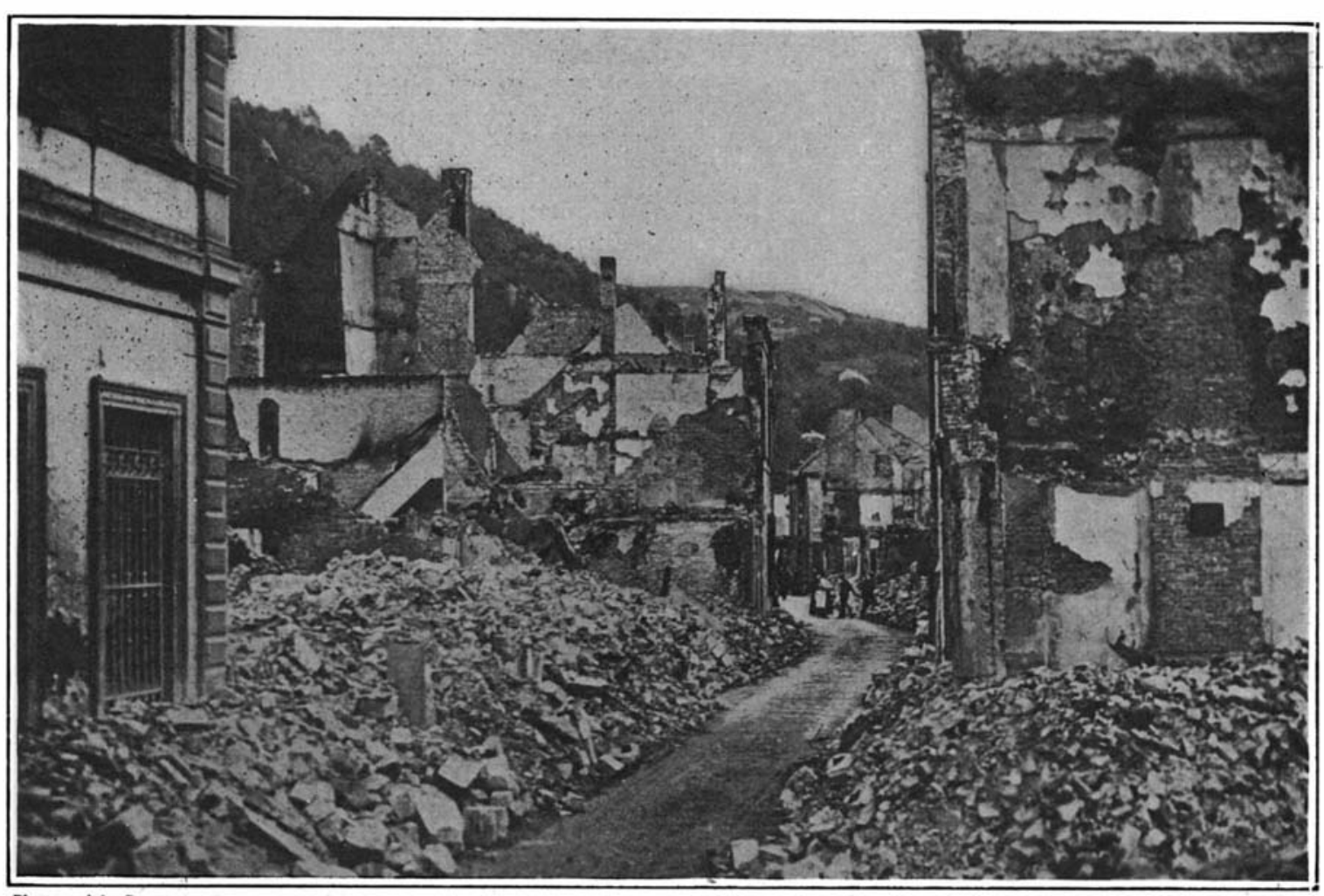

In the wake of the Germans. Whole French villages have been reduced to crumbling ruins.

the same day that the British were driven from Mons by the Germans who had passed through Brussels. At last the Germans could leave Belgium behind them and begin the long delayed invasion of France.

France in the Early Days of the War.

In the meantime the French had completed their mobilization and had put in operation the plan of their general staff for the opening of a campaign against Germany. They were not disposed to permit Germany without a serious struggle to assume the initiative in to lose none of the advantages gained by her violation of Belgian neutrality.

The German War Machine Rolls On. With all the precision and energy of a smooth running powerful machine she began her memorable ad vance from the Belgian frontier which was not to be stopped until the very gates of Paris were reached. Like a huge gate hinged on the fortress of Verdun, her long line swung through northern France to close the (Ooncluded on page 125) 
The First Year of the Great War (Concluded from page 111)

hundred and fifty mile gap to Paris. Tim and again the greatly outnumbered French and British valiantly took defeat in their effort to hold back the German tide long enough to permit of a readjustment of the French forces before the German gate had swung shut on Paris. The battles of Cambrai, St. Quentin, Guise, Launois, Le Fere, Amiens and Rheims were but mile stones along the road of Germany's tr umphal march, which was not halted until September 7th, when the Germans were across the Marne and extended on an east and west line from Verdun to Paris Throughout this disastrous campaign the French people kept their self-contro and supported their commander, who wa gathering together his forces for the battle that was to decide the fate of the French army. The government was re moved to Bordeaux and Paris prepare for siege, and still the French wisely re fused to accept a decisive battle befor the scales indicated that the weight of numbers and the advantage of position had shifted in their favor. The victories of Russia in the east compelled Germany to send troops from France to the eastern theater, and Belgian attacks from Ant werp were drawing additional forces from the fighting line to protect the long line of communications. On the other hand France was collecting every available soldier and England was rushing her troops to the Continent. Finally, on September 6, the day had arrived for the supreme blow of the French army, and the battle of the Marne was begun.

The First German Reverses.

From Paris on that day the garrison of the city and the British army fell upon the exposed right flank of the German army, but five miles away, and almost completely enveloped it. Still the Germans did not give up all hope of delivering the final blow which would give their great drive on Paris a successful ending, and to the east of Paris they concentrated for a powerful assault on the French center. Their failure here and the threatened disaster to their flank completely turned the tables, and by September 10th the German host was retreating precipitately over the same roads they had used in their triumphal advance only a few days before.

The French had tasted victory and their pursuit was spurred on by the hope of destroying the entire right wing of the invading army, but the Germans were able with desperate fighting to rally behind the Aisne River. This was September 12th, the day that marked the beginning of the battle of the Aisne, the most desperate struggle up to then in the war. For days the battle continued, but in the end the Germans had rearranged their lines and were in strong possession of their position, and it became evident that France was not to be freed of the invader.

During this trying period for Germany, the Belgian army that had fallen back to the north of Antwerp when Brussels was captured in August, became such an annoyance in the German lear, that the capture of Antwerp was undertaken. With incredible swiftness the Germans carried out this operation against a fortress supposedly strong enough to withstand a siege of many weeks. The siege was begun September 28th and Antwerp fell ten days later, but the bulk of the Belgian army made good its escape to the west and robbed the Germans of the choice fruit of their victory.

Then began the series of desperate struggles on the northern wing of the long battle line in which the two armies vainly tried to outflank each other and gain a decisive success. The most important of these was the fighting about La Bassee and Ypres in the last half of October, the battle of the Yser in the last week of the same month, and the battle of Ypres in the first half of November. Back and forth flowed the tide of battle without either side gaining any decisive advantage. The battle lines were gradually exand with this barrier against enveloping

movements in the north and Switzerland barring similar operations in the south the opposing forces settled down to the indecisive although oftentimes desperate trench warfare that characterized the fighting on the western front throughout the winter and until the present time. Both sides occupy to-day practically the same positions they held at the beginning f this calendar year.

\section{The Early Russian Successes.}

Throughout the early weeks of the war the operations in the west were of such magnitude that the less stirring events in the eastern theater attracted minor attention. Russia's mobilization progressed more speedily than was expected, and early in the war she checked Austria's attempt to carry the war into Russian territory, laid secure hold on the initiative, and, so far as Austria was concerned, held it for many months: Russia was confi.onted by weak German forces on her German border and by the bulk of the Austrian army farther south. Her plan for a time was to play a minor rôle against Germany, while concentrating overwhelming numbers against Austria. If she succeeded in destroying the Austrian army, she would turn her full strength against Germany. She was compelled by the success of Germanys' drive into France to come to the assistance of her western allies by a more vigorou campaign against Germany than she had originally planned. About the middle of August she began her advance into East Prussia and found little difficulty in pushing back the weak German forces in her front. By August 24th the great fortress

of Koenigsberg had been passed by and isolated, and two days later Allenstein was occupied. It began to look as if her victorious march would not be stopped hort of the fortified line of the Vistula River. But Germany sent from the west corps she could ill spare from her ampaign against Paris, and on September 1st they gained, at Tannenburg, the first of many brilliant victories to be won German arms in East Prussia. Two ussian army corps were all but dethe rout was so complete that ussia did not recover until after she wa riven from East Prussia in the middle of September. Still the campaign was not barren of results for the Allies, for t t had subtracted two corps from the German army in France at a critical stage of its perations.

In the southern portion of the Russian theater, Austria began her advance through talicia toward Russia as soon as she had completed her mobilization. The left wing of her army advanced between the Vistula and Bug Rivers into Russian terri$y$ and won the battle of Krasnik on ugust 28th, but the victory was nullified y the severe defeat of the center before Lemberg two days later. Still, two days later the right wing from the Carpathians to the Dniester River was driven back and the fortress of Halicz was taken. The disaster was made complete by two more ictories at Rawa Ruska and Tomaszov over portions of the Austrian army that were trying to escape. The retreat became practically a rout and another stand was not made until the fleeing army had reached the line of the San River, seventy miles west of Lemberg. This position naturally secure, received additional strength from the two fortresses of Jaroslav and Przemysl. By September 16th they were in this position, but were able to hold it Przemysl the Russians crossed the San, surrounded and laid siege to that fortress, captured Jaroslav, and once more put the Austrians to flight. This time the deeated army continued its march to the rear for eighty miles until it reached the line of the Dunajec River but fifty miles east of Cracow, an important strategic point on the western border of Galicia. The Austrian defense was crumbling away and help must come from somewhere. Once more Germany had to jeopardize her campaign in the west to meet the oncoming Russian horde in the east. Seven pose and the outcome of the German cam-

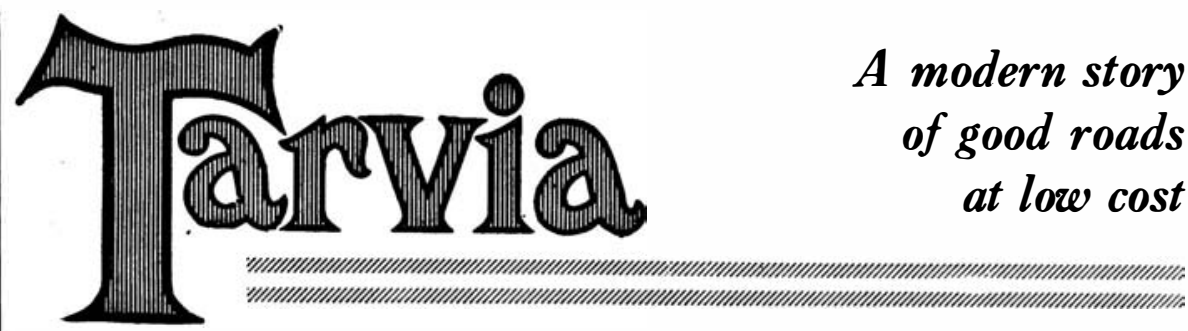

$A^{L L}$ over the country movement in favor ot better roads.

Taxpayers are beginning to realize that good roads are an asset; poor roads a liability.

The proper kind of roads in a community means in creased property values, more accessible markets, reduced transportation expenses.

The important question now is - "Can good roads be built at low cost?"'

The answer is - "Yes, if Tarvia is used - and here are the facts.'

For many years, outside of the heavy traffic zones in large centres, macadam roads were recognized as the most economical and satisfactory.

The advent of the automobile changed this Macadam roads, as then constructed, rapidly disintegrated under moto car traffic.

French engineers were the first to make this discovery. They, also, were the first to find a remedy, namely, the use of tar preparation instead of water in building macadam roads.

In this country, the Barrett Manufacturing Company took up the problem in 1902 and developed Tarvia in various grades. This

treatment was wonderfully successful, resulting in bet ter roads at lower cost than ever before.

Since that date thousands of miles of roadways in this country have been treated with Tarvia, and today a tarviated roadway, with its firm, easy traction surface, free from dust and mud, is a blessing to hundreds of communities.

A tarviated roadway is durable enough to be called permanent, because it is strong enough to endure modern automobile traffic.

The first cost of building a tarviated road is not greatly in excess of the cost of constructing plain macadam.

The saving in maintenance expense, however, is usually greater than the cost of the Tarvia treatment.

In other words, a tarviated road is really less expensive than ordinary, dusty, muddy water-bound macadam.

Most modern engineers and road authorities recognize these facts, but we are afraid they are not generally understood by the public.

If taxpayers realized that at practically no extra cost they could secure a firm waterproof, dustless and mudless road they would be far more strenuous in their demands that tarvi- 

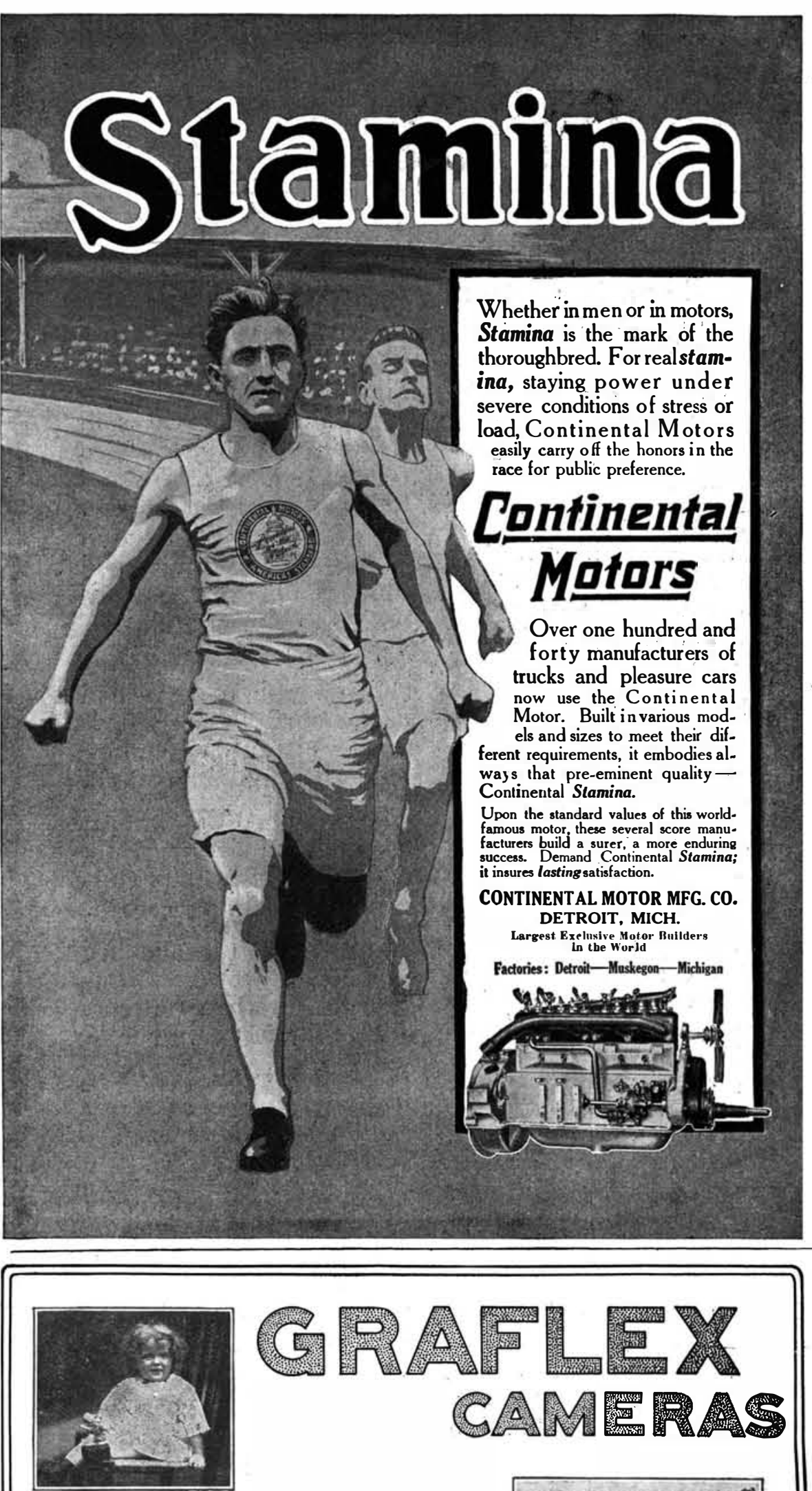

PICTURES LIKE THESE ARE EASY TO MAKE-when you use a Graflex Camera.

In shade or sun, indoors or out, the Graflex is always ready to make the kind of pictures you have always wanted. And when you use a Graflex there is no uncertainty A glance in the focusing hood shows the image the size it will appear in the finished picture, right side up, and the image remains brilliantly visible up to the instant of exposure. It is not neces. sary to estimate the distance between the camera and the subject; focusing scale and finder are done away with.

Every Graflex Camera is equipped with a Graflex Focal Plane Shutter-the shutter that works at all speeds from "time" to 1.1000 of a second, and enables your lens to work at its full efficiency

Graflex Cameras are fully described in our 64-page illustrated Graflex Catalog. Your copy will be mailed for the asking.

Folmer \& Schwing Divisior EASTMAN KODAK COMPANY Rochester, N. Y paign against France was no longer in Germany was again forced to come to the doubt. But these re-enforcements, to- rescue of Austria. Taking advantage of gether with the campaign Germany now her wonderful system of strategic rail began in Poland, saved the Austrian army roads along the Polish frontier, she hastily from annihilation.

The Second Invasion of Poland by

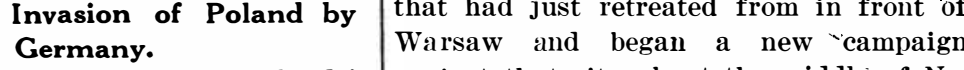
A second German invasion of Poland in against that city about the middle of NoNovember and December gave the Aus- vember. For more than a month the ad trian army, then greatly recovered, an vance continued and for a time it looked opportunity to undertake an offensive as though the Germans would gain a demove intended to drive the Russians from cisive victory; but strong Russian forces the vicinity of Cracow, clear Galicia and were hastily collected in Warsaw, the raise the siege of Przemysl, but the cam- German army was halted at the Bzura paign was a failure, and at its close the River and then nearly surrounded by the Russian armies renewed their advance two powerful Russian forces coming in all the way from Bukowina to Cracow. opposite directions from Lodz and WarEarly winter found her at the foot of the saw. No previous crisis in the war had passes of the Carpathian Mountains gath- been so serious for the Germanis, and only ering her strength for an advance across by the greatest skill, together with rethis barrier to the plains of Hungary. But enforcements from the French frontier, by February Germany was able to come were they able to extricate themselves by February Germany was able to come were they able to extricate themselves
to. Austria's aid with large re-enforce- from the ring that was closing around to Austria's aid with large re-enforce- from the ring that was cond found them
ments of new troops, and once more the them. The end of December found Teutons assumed the offensive all along driven back once more to their old pothe extended southern front. For many sition.

weeks the struggle continued along the In the meantime the German advance northern slopes of the Carpathians and in through East Prussia to the north after Bukowina and for a time the Russian ad- the defeat of the Russians at Tannenburs vance was brought to a standstill or had continued across the frontier to Aupushed back. But with the surrender of gustowo, where it was turned back early Przemysl, on March 22nd, this weight was in October. Through November, December removed from the Russian rear, four and January the Russians pushed slowly corps were released for the front, and but steadily westward in this region, and preparations were at once made for the once more occupied East Prussian terrilong-heralded advance in Hungary tory. Finally, in the early part of FebruRussia's hosts were now available and ary the Germans assembled a powerful for some time they had been concentrat- army south of Koenigsberg, covering the ing for this grand advance into the heart concentration by a feigned attack on Warof Austria. By the end of March they saw by their army in Poland to the south, were ready and the movement across the attacked the Russians when they were in mountain barrier was begun in the dead the difficult region of the Mazurian Lakes co other battlefields, still was able to send cisive victory of the war, and completely other battlefields, still was able to send
fresh corps to help protect the Carpathian
routed the Russian army. After this vicfresh corps to help protect the Carpathian routed the Russian army. After this vicpasses, but the Russian advance seemed tory, fighting along the entire front irresistible. The advance began in the through Poland and East Prussia grat last days of March, and by the middle of ually became of minor importance, but th April it had crossed the mountains and Germans continued to hold on securely the two weeks of inactivity that followed the territory they had won in anticipationrations for the most spectacular and de- paign against Warsaw, which is now becisive campaign of the war-the campaign ing waged.

that began, May 3rd, with the terrific German drive from Cracow against the Russian flank in the Carpathians, compelled Russia to abandon her invasion of of the war and immediately Hungary, drove her armies in rout from diplomatic struggle between the ablest the mountains, recovered most of Galicia, diplomats the contending powers possessed inflicted one serious defeat after another - one side endeavoring to induce Italy to on the retreating Russian army, and remain neutral, the other exerting every finally placed the Teuton armies in a fa- effort to get her to join in the war. The vorable position to undertake the final latter party finally won and Italy joined grand climax of the campaign now being forces with the Allies in the latter part fought out about Warsaw. $\quad$ of May. She had made her preparation How Strategic Railways Saved Germany. most deliberately and was ready to sta Throughout the war the two great cam- her armies in motion the moment she depaigns in the east and west, Germany clared war. The main routes from Italy against France, England and Belgium in into Austria are to the north across th one theater, and Russia against Germany Alps and through the Trentino, and to the and Austria in the other, have exercised east along the northern shores of the Adri a controlling influence on operations in all atic Sea. Italy's plan was to guard the other theaters, including Poland, East northern lines of approach with weal Prussia and Servia, and even the more forces, while sending the bulk of he important operations in Italy and the Dar-forces to invade Austria by the easter danelles, for the grand decisive victories route. For two months she has delibe that will give victory to one side or the ately and methodically followed this plan other will be won in one or both of these At the Isonzo River on her eastern fron main theaters, and the main purpose of tier she was met by the Austrian arm operations in minor theaters has been to supported on powerful fortifications an influence the outcome in the two main for weeks she has been hammering at th theaters. This was the object of the first line. As this is written rumors reach German campaign in Poland. In Septem- that Austria's main defensive bulwark ber, Austria was badly in need of assist- Gorizia is about to fall. Although Italy' ance and Germany gave it by advancing own campaign has yet to succeed, east through Poland on Warsaw. The doubtless has greatly influenced events movement began about October 1st and the eastern theater of war, for who ca continued successfully for three weeks predict what the outcome in Russia mig until the outskirts of Warsaw were have been if the Austria army on th reached; here they were attacked on their Italian frontier had been free to tak unprotected left flank, defeated and part in the desperate and successful cam thrown back. By the latter part of Oc- paign the Teutons have waged again tober the German force was in full re- Russia since the early days of May.

tober the German force was in full re- Russia since the early days or May.
treat. The pursuit of the victorious Rus-
In the last days of October the form treat. The pursuit of the victorious Rus- In the last days of October the forme
sians continued throughout the first half of
German battleships "Goeben" and "Bre November and was not stopped until they lau," sailing under the Turkish flag, fir were looking across their frontier into on Odessa in the Black Sea and announce Germany. At the same time the Russians to the world that Germany had at la in East Prussia recovered from their succeeded in embroiling Turkey in th earlier severe defeat at Tannenburg, were war. This was the signal for an advan once more advancing on Koenigsberg, and against Turkey from all sides. From t their armies in Austria were victorious south along the Euphrates River came everywhere. This being the situation, British army, and from the north can 


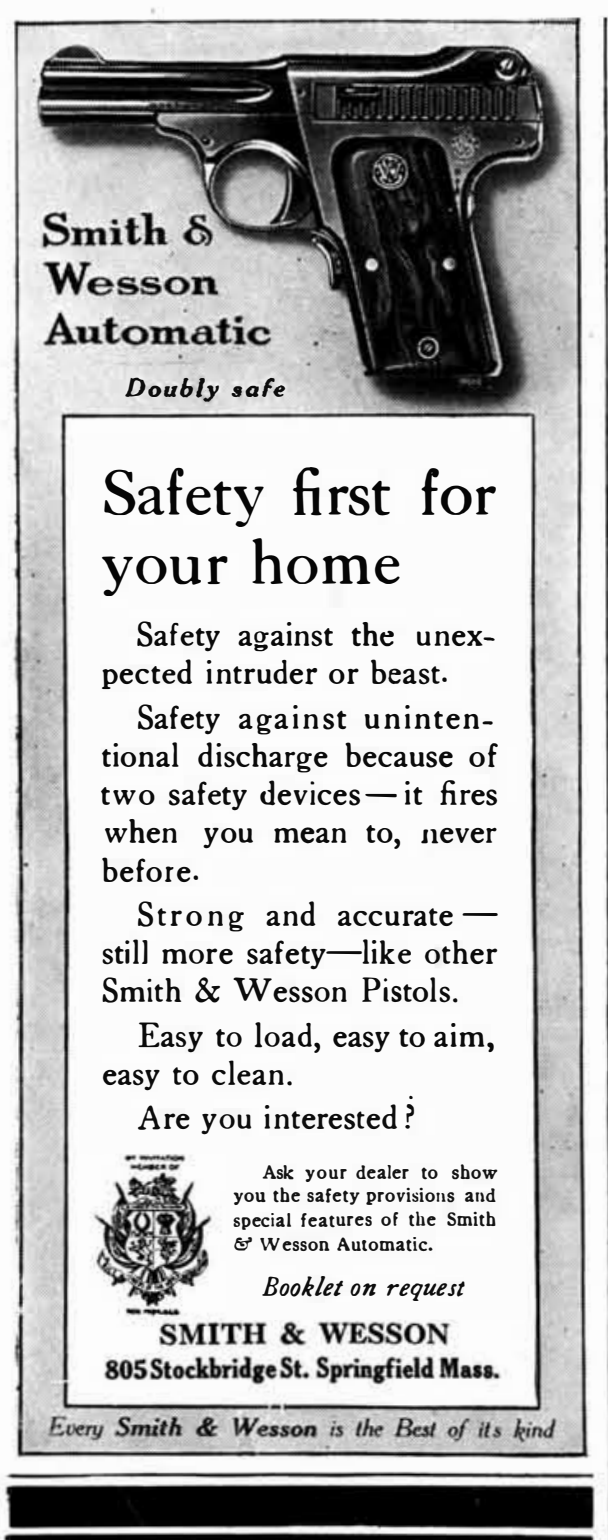

If there is an ingredient for paint that will make it wear longer and look better on your house, don't you want to know it?

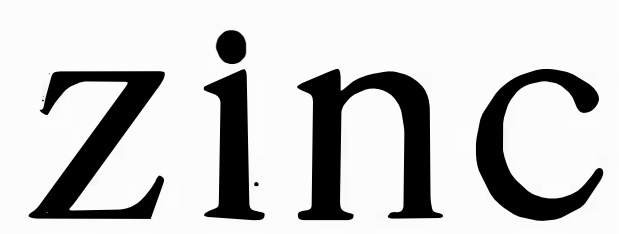

is the name of that ingredient. Now you know.

"Your Move" is a book that supplies sufficient
information for you to act upon.

The New Jersey Zinc Company Room 421, 55 Wall St., New York

For big contract jobs consult our Research Bureau

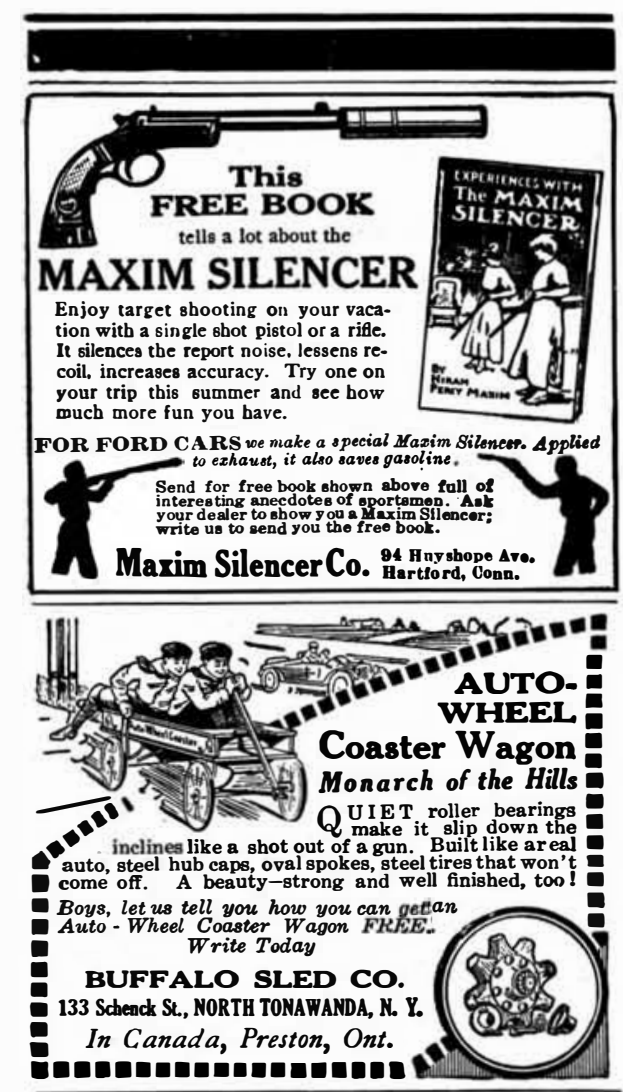

Valuable Books of Instruction and Reference

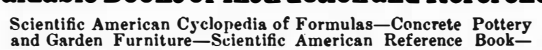
mUNN \& CO., Inc., Publishers, Wootworth BIdz., New York the Russians, while a second British army gathering at Suez was in a position to move east against the railroad to Mecca; lastly a combined fleet appeared fighting was in the Caucasus, and culminated on January 4 by an overwhelming defeat of three Turkish corps by the Russians. So far the principal benefit the Teutons had secured from her ally resulted from the closing of the Dardanelles as a supply route for Russia, now limited to Archangel, an ice locked harbor during a large part of the year, and Vladivostok connected to the fighting line by a single track railroad many thousand miles long. To open the Dardanelles and to reach Constantinople, the British and French finally anded an expedition on the narrow Galipoli peninsula. For months this force has been steadily creeping nearer to the forts that are the key to the peninsula and the straits.

A year ago the assertion frequently was made that the Teutons would meet with their greatest success in the opening onths of the war, and that the greater numbers and superior resources of the Allies would soon begin to tell. The truth has turned out to be just the reverse. The Teutons' star was never so dim as during the first few months of the war, and never so bright as now at the end of the first year. Their resources in trained soldiers have been vast enough to enable them as the war progressed to overcome for man on the battlefields, while in ammunition and other essential war materials their supplies have been greater than those of the Allies. With a condition of stalemate in France and the Dardanelles, and Italy checked on the Isonzo, while victory perches on the banners of the Teutons in Russia, the beginning of the second year of the great war promises to mark the beginning also of the first decisive stage of the conflict

Twelve Months of the Great Naval War

Concluded from page 109.)

the British Isles, submarines have scored no successes against naral vessels.

There is little doubt that it was the menace of the submarine that forced the British main fleet to seek a distant base, remote from the North Sea. Touch is kept with the German coastline, probably by a blockade of submarines, and it may be the presence of these off the German ports which is largely responsible for the abso lute German immobility so far as its battleship and battle-cruiser fleet is concerned.

paratively new rranean this same comdemonstrated its efficiency in dramatic fashion. The Austrians have sunk one of the finest of the French armored cruisers and an Italian cruiser, and lately in the Dardanelles the German submarines have accounted for two of the older British battleships, the "Triumph" and "Majestic." The British submarines have sunk two Turkish cruisers and a German cruiser, "Hela," in the North Sea, and the French and Italians have scored frequently in the Mediterranean.

Just here, with regard to the Dardan elles operations as a whole, it should be said that the attempt to force the Straits by a naval demonstration unaided by land forces was one of the worst blunders of the whole war. The first reports of this adventure were optimistic and aroused an expectation of success which was altogeth er unwarranted by the facts. It has been rumored that the Allies expected Greece to furnish the land army for co-operation but this has never been substantiated The present operations promise succes after slow and arduous fighting. That the Gallipoli peninsula is being won by the Allies is another tribute to sea power ; for every man, every gun and every pound of provisions for the large army there had to be transported by sea and the army itself provisioned and munitioned from the sea Furthermore, the ships are lending most valuable aid by their flanking fire in as sisting the army to conduct its sweepin

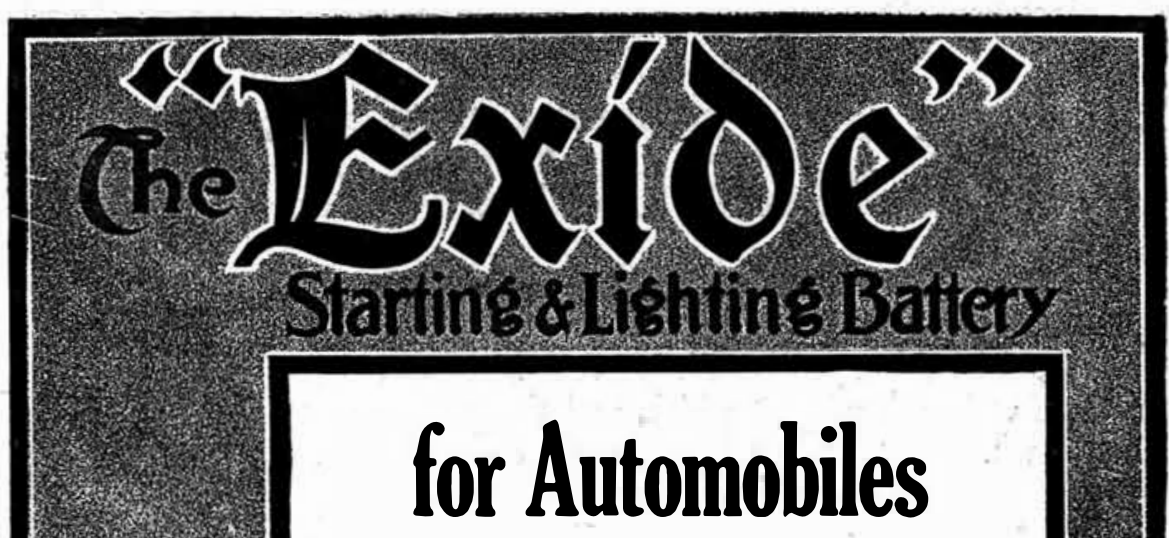

is used by over 250,000 motor car owners

THAT little battery that furnishes the power to crank your motor is about the biggest little thing you can imagine. Do you realize it must develop from one to two horse power every time you start your engine?

It must do this job over and over again, day after day, winter and summer. Doesn't your battery get less attention than any other working part of your car (it is so with most owners); therefore shouldn't you have the best battery that can be bought?

"Exíde" Batteries are so largely used because they are made rightmade by the oldest and largest storage battery maker in the country.

27 years of specialization make possible the following exclusive features:

1 THE UNISEAL ASSEMBLY. Each cell is 1 a separately sealed unit readily removed from the case. Experienced battery men endorse this "IExide" feature. No other starting battery possesses it.

2 FLOOD PROOF FILLING PLUG. The 2 "Exioe" plug automatically prevents over-filling. Rotting of battery cases and corrosion of metal parts of the car are prevented by this exclusive patented feature.

3 TOUGH, SEMI-FLEXIBLE JARS. These new "Exide" jars perm it the unit assembly by eliminating the objectionable packing compound. The jars are expensive, but jar breakage in "IExíde" service is very rare.

4 GREAT STARTING ABILITY. The uni4 seal construction permits an increase of $15 \%$ to $20 \%$ in the plate area and consebatteries, as compared with other batteries of equal size and weight.

5 LOCKED CORNER CASES. "EXXide" 5 Starting Battery cases are strongly constructed of hard wood with locked corners and firmly anchored handles.

THESE and OTHER " EXIOCe" FEATURES make the "Exide" Starting Battery the highest priced battery on the market. They are real service points which appeal alike to the engineer and to the practical motorist. i Before you pay less, be sure you want less.

The book with a helpful punch behind its laughter"A Sure Start Assured." Send for it. It's free.

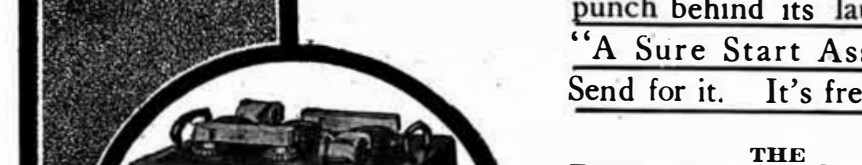

Electric Storage Battery Co 1888 PHILADELPHIA 1915

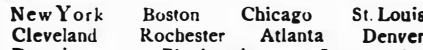

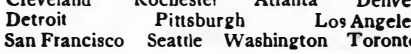
"Exide" Service Stations throeghtoot the U. S. 